\title{
WAYS TO IMPROVE ORGANIZATIONAL EFFICIENCY OF TERRITORIAL DEVELOPMENT AND POST-CONFLICT STABILIZATION IN UKRAINE
}

\author{
Pavlo MUZYKA \\ Lviv National University of Veterinary Medicine and Biotechnologies named after S.Z. Gzhytskyi, Ukraine \\ Maksym FILIAK ${ }^{2}$ \\ Lviv University of Business and Law, Ukraine
}

\begin{abstract}
The purpose of the paper is to advise to optimization improvement pathways in territorial development and post-conflict stabilization in Ukraine that currently undergoes change from the «firefighting» real-time operational mode to the routine bureaucratic mode. The major challenges include the resolutions of deficient operational models such as: forgetting, chemical dependency of management, inability to make decisions, reluctance to start a dialogue, «cut-off» solutions and some others. Methodology. A desk and in-depth study is carried out of several national territorial stabilization programs dealing with the government that ensure infrastructural support to post-conflict regions and communities in the East of Ukraine. It is studied how the programs are managed by the controversy of the results-based and process-based approaches (2015-2016 data) via NGOs and subcontractors. Improving stabilization tools, it leverages transformation of its own systems into a firm yet flexible entity. Results of the research showed that stabilization project systems should seek a balance between the results-based and process-based ends of management, the first focusing on quicker and more flexible lower-level results, and the second building bureaucracy via continuous processes. Practical implementation. Regional subcontractors can improve satisfaction and widen participation by supporting informal initiative from the grassroots level. A good solution to resolve operational conflicts is hiring a helping hand to the administrator - a typical results-based manager who will help follow the harmony to achieve immediate results. Any improvement in the transparency of the system and the formalization of relations between the beneficiary and the subcontractor, shifted in addressing issues at the level below, does not require exclusive access to the principal decision-maker, and would simply and easily be implemented at the technical level of the beneficiary institutions. Value/originality. The article concludes with the statement of the two radically different approaches to management systems that work in such projects, the first on the basis of a result, and the second in the process, and the two being incompatible. There are people and organizations propagating result and work to achieve it, but working with the staff aimed at the process because they can either not reach or stretch operation, hoping that they will thus extend their contracts.
\end{abstract}

Key words: development program, stabilization and support assistance, results-based management, bureaucracy, efficiency.

JEL classification: A13, A23, J11

\section{Introduction}

Personnel and organizational management system deficiencies in recovery program areas have become critical by early 2016 with the need to tackle the extended conflict in the East with a more systematic manner, apart from the «firefighting» strategies that have been commonly used in 2015, and therefore the program management has began considering the various ways to combat these imperfections and obvious downsides in the view of the need to carry on with the extended conflict situation of the «slow fire» in 2016 and possibly 2017.

The selected case study descriptions of the above research are presented below in form of the short findings. They all describe organizational and personal downsides experienced by post-conflict territorial stabilization programs, and suggest solutions as visible from the current perspective.

\footnotetext{
Corresponding author:

${ }^{1}$ Department of Economics of Enterprise, Innovation and Advisory Services in Agriculture,

Lviv National University of Veterinary Medicine and Biotechnologies named after S.Z. Gzhytskyi.

Email:myzukapavlo@ukr.net

${ }^{2}$ Lviv University of Business and Law.

Email:maxym.filyak@gmail.com
} 


\section{The project manager that forgets}

This seems to be a good person and an acceptable manager - but there is no integrity of thought and no transmission of promise in his mind. That is, in a conversation, he/she pays attention to unimportant details, «switches on» and forgets about whether there is still anything important that he/she really needs to mention, and, when recalled - swears that he/she was really talking about this important thing. In this mental obscurity, there is an advantage, as such manager can «blow in his verbal jungle», and then he/she completely forgets the issues that were discussed - and no longer presents any of the issues of his/her «wild ideas» to any colleagues or partners. The main thing that the colleagues should somehow watch that he/she should not forget any critical thing, because then alter, as the consequences of omitting a really serious thing can become significantly more expensive, this «forgetting manager» will usually dump the blame on someone else - but not himself. If he/she is smart and realizes the «forgetting downside» of his/her mind, then he hires a personal assistant - quality-focused, older, sophisticated and somewhat autocratic secretary.

\section{Middle management dependent on sedative drugs}

You can rarely find anything which is more dangerous than that quiet middle management is dependent, in their lives, on the sedative and «life-affirming» chemicals and pharmacy. The problem is not in the chemicals as such - it lies in the fact that the manager relies on the chemicals too heavily and becomes heavily addicted. Then, if he or she did not take a pill today, the personality is deforming itself and shows its true inside without embellishment, and even more - demonstrates even a mental strain that developed in such person since the start of active use of the sedative drugs. Thus, vital solutions in the project's or organization's life seem to depend on one or two tablets taken in time - or not taken. Such people should not have any place in any top program management.

\section{Eternal non-decisiveness and fear}

The study showed that there operate some organizations and projects, even fairly large and prestigious, where work in unexplored areas is accompanied by the wish of key personnel to avoid any responsibility for decisions (although the process is essentially an assembly of the known modules that only a few people have ever gathered together, and we are not speaking about any really hi-tech innovativeness), and it is often accompanied by the fear of being laid off. Why are they afraid of? They are, because they do not see any broader picture and at the same time realize their inability to produce a result «at a glance». In addition, their large hierarchy is guided by people who are, in turn, guided by the «collective-building» approach to results-based management. That is, they approach a «mind-changing» intellectual organization as a construction site where they are free to temporarily hire and fire foremen and their «construction teams» - and sometimes so quickly and dramatically, that the next team does not understand what it is building today, and why.

\section{Reluctance to start a dialogue}

Another strange feature identified by the research, which goes against the democratic traditions is noticeable in the discussion and decision-making in the organization or project. This downside is the failure of program senior management to start a dialogue with the mid-level management of with sub-contractors. If the hierarchy of the organization allows explaining this «peculiarity» by national or ethno-cultural management (as it is often international management that does not want to talk to the local implementers), something very strange which has been noticed here is the impossibility of such dialogue with independent sub-contractors, which are in the same center of decision-making as the top management at the «customer» side within the framework of such a development program. The question is not even in the fight against the status, but rather in the need to address issues really needing practical attention of both parties every 1-2 weeks of the project. To create an atmosphere of dialogue, a usually more concerned smaller party finds it necessary to seek contacts and intermediaries to appoint a meeting, and at one time «push» the necessary decisions. On the other hand, this deficiency could easily be remedied by establishing a dialogue, although it must be recognized that the initiator will still be the most interested party, and as a rule, it is not the largest player in this situation. It should be noted that to talk to the decision-maker, one need to avoid any gossip or fear on the part of the many employees of the «customer» side.

\section{6. $\ll$ Cut-off $\gg$ solutions versus harmonious move}

If during the critical, fast project deployment phase of the program, the implementers are encouraged to fragile, but creative action in «sprinter mode» of operation, then on the phase when the uncertainty has become «dragged in time» and prolonging into further instability, then the «sprinting» staff often fails to «drudge» the routine processes that emerge. Therefore, the top management sends an administrator to the field - the one capable of restoring order, but often also transferring the administrative methods on the field management staff that has been recently accustomed to unusual and unforeseeable circumstances. This administrator is either feared, or listened to, in the hope that he/she will soon be replaced. However, such administrator does not particularly understand the interconnection between conditional critical work paths and intermediate results of operations. A good 
solution is hiring a helping hand to this administrator a typical results-based manager who will help follow the harmony to achieve immediate results.

\section{Focus on destruction}

Management to restore the programs attracts strange type of people to the operational program management level. Especially, and it can be shown, the people previously engaged in rapid response to natural disasters and calamities in other parts of the world. We call them destructionists because of their specific approach to management and attitude. When they work on the project of «restoration», in fact they want to fracture their reality and often become accustomed to it. Often in other parts of the world they are in situations of natural cataclysm, where social capital cannot be restored (at least within the terms of the project), and the infrastructure is damaged irreversibly (Pischulina, 2009). When they work in «restoration», they unconsciously want to be inside this destruction. However, if their colleagues and subordinates do not destroy, but build, that is equal to restoring, then the «destructionists» start destructing their own colleagues, partners and subordinates. They literally mentally, morally destruct from the inside, wear out their labour potential (giving a bunch of unnecessary instructions, setting unrealistic deadlines and loading work, and then suddenly dismiss those who are already «empty». They need to obviously return to the settings and territories of destruction and our territory, in order to stabilize the conflict, should attract real «builders» and «renovators» to stabilization projects.

\section{Strange doubles}

On the side of the program beneficiary sometimes a strange, though explainable phenomenon can be observed - the one of irrational dubbing. On the one hand, there are entire departments or positions that partially duplicate each other's functions. However, the really important functions have no duplicates, and if, say, a person with a «key organizer» of the meeting that is just listening to the first deputy is gone on vacation, then there is no one to replace him or her. Moreover, work in this direction halts because there is no one else to perform it and this is an essential function. How to fix it? Probably, any improvement in the transparency of the system and the formalization of relations between the beneficiary and the subcontractor, ever shifted in addressing issues at the level below to the question, that does not require exclusive access to the «big boss» of the beneficiary organization, and would be simply and easily be resolved at the technical level of the beneficiary institutions. At the level of state structures, a successful project is better managed at the level of competent heads of departments than at the level of permanent employment and way affiliated with the big boss alternates.

\section{Visible conflict of the process and the result}

There are two radically different approaches to management systems. The first is set on the basis of a result, and the second on the process. It is incompatible approaches. There are people and organizations propagandize result and work to achieve it, but working with the staff, aimed at the process because they either cannot reach or stretch operation, hoping that they will thus work longer. People from the «process» cannot take the job, providing results, and vice versa, although the latter is true only in part («results-oriented $»$ still can get used to the role of «process-oriented $\gg$ but consider it a perversion). Effectiveness often depends on the quality and experience of key personnel (Filyak, 2013), but also, and even more by filling the «fabric» of the organization, that is, from the mid-level professionals. If all of them at this average level are replaced by inexperienced students, even super-productive leader ceases to be such and fails the larger tasks. Thus, it is the average level of experts that determines the mood of the company, its task-focus and professionalism. Again, it is noted that «results-oriented» people are more democratic and unite smaller groups (there is a need only in the necessary links in the chain), while the «process-oriented» build complex and threedimensional hierarchy.

\section{Tensions between the results-based and process-based «ends $\gg$ of the program}

In territorial revitalization management systems, the project begins first case as a results-oriented, but then, enhanced by the character of the middle management and the slightly unexpected nature of the development of the subject in a very dynamic areas, this project develops into a «dragged-in» process, which, however, due to the document success indicators inherent in the project, search through jobs involving all hands to show the result of a planned or an imitation of «tomorrow $»$.

If the organization is configured in the result, it is better to have the highest level of secretariat and level of people belonging to the «results-oriented» ideology, while the average level can be filled by the «processoriented $\gg$ staff. If the organization is set up in the process (e.g. education), they have the middle tier (managers) working on the result, while the leaders - charismatic visionaries, as well as secretarial staff, and often teachers (line performers) and so on are engaged in the process. Otherwise, the «results-oriented» manager will be driven off the playing field, making the high-quality work for the process-based chief who often wants unnecessary procedural makeovers. Worst of all, however, the head that focuses on results but does not know at all how and when he should take to achieve the process. They are sometimes thrown from side to side, and if they do not admit this defect and refuse to learn, they also become a ramshackle structure as a result. 


\section{References}

Filyak, M. «Managerial scratch notes» of Phase 1 Project. «Gromadski Initsiatyvy». (13): 3-4.

Business planning in small cooperative entrepreneurship. - Chasopys Publishing - 2013.

Filyak, M.S. Outcomes of Phase 2 micro projects' potential and sustainability analysis. «Gromadski Initsiatyvy». (21): 8-16.

Pishchulina, O. New jobs in Ukraine: Results and Prospects. Department of Economics and Social Strategies. Retrieved from: http://old.niss.gov.ua/Monitor/october09/15.htm

A National Monitoring and Situation Analysis System (excerpts for Round 1). «Gromadski Initsiatyvy» (32): 2-10.

\section{Павел МУзИКА, Максим ФИЛЯК}

\section{ПУТИ ПОВЫШЕНИЯ ОРГАНИЗАЦИОННОЙ ЭФФЕКТИВНОСТИ ТЕРРИТОРИАЛЬНОГО РАЗВИТИЯ И ПОСТКОНФЛИКТНОЙ СТАБИЛИЗАЦИИ В УКРАИНЕ}

Аннотация. Целью работы является определение путей оптимизации территориального развития и постконфликтной стабилизации в Украине, - систем, в настоящее время подвергающихся изменению в переходе от подхода на основе «тушения пожаров», в рабочем режиме реального времени - к общепринятому бюрократическому построению работы. Основные задачи включают в себя анализ дефицитных оперативных моделей, таких как: забывания, химической зависимости системы менеджмента, неспособности принимать решения, нежелания начать диалог, радикальных решений и некоторых других. Методология. Было проведено кабинетное и фокус-групповое исследование ряда национальных программ по стабилизации, в которых государство выступило партнёром и которые обеспечивают инфраструктурную поддержку в постконфликтных регионах и населенных пунктах на востоке Украины. Было изучено, каким образом программы ведут полемику между ориентированным на конкретные результаты подходом и технологическими методиками, основанными на данных 2015-2016, от НПО и субподрядчиков. Улучшая инструменты стабилизации, программы использует преобразование своих собственных систем в структуре, на гибкой организационной основе Результаты исследования показали, в целом, что системы проектов по стабилизации должны искать баланс между ориентированным на конкретные результаты подходом и основанных на процессах методах управления, - в котором первый подход делает упор на более быстрые и более гибкие результаты более низкого уровня, а второй подход строит бюрократию с помощью непрерывных повторяющихся процессов. Практическое значение. Региональные субподрядчики могут повысить удовлетворенность и расширить участие за счет поддержки неформальной инициативы низового уровня. Хорошее решение для решения оперативных конфликтов - это дополнительно нанять менеджера по поддержке администратора - то есть типичный менеджер, ориентированный на результат, который поможет администратору следовать гармонии для достижения немедленных результатов. Любое улучшение прозрачности системы и формализации отношений между бенефициаром и субподрядчиком, сдвинутые в решении проблем на уровень ниже, не требует исключительного доступа к основной фигуре, принимающей решение, и может быть просто и легко реализовано на техническом уровне учреждений-бенефициаров. Значение/оригинальность. Исследование завершается утверждением о двух принципиально различных подходах к системам управления, которые работают в таких проектах: первый на основе результата, а второй на базе процесса, и оба они в целом не совместимы. Есть люди и организации, ориентированные на результат и работающие для его достижения, но работающие с персоналом, направленным, наоборот, на процесс, так что они не могут либо не достигают необходимых результатов и затрагивают процессы в надежде, что они смогут таким образом продлить свои контракты. 